\title{
PENGARUH METODE PEMBERIAN RANSUM PADA SIANG DAN MALAM HARI TERHADAP BOBOT HIDUP, BOBOT KARKAS, DAN GIBLET AYAM JANTAN TIPE MEDIUM DIKANDANG POSTAL
}

\author{
The Effect of Method of Giving Rations Day and Night on the Live Weight, Carcass Weight and Giblet \\ Weight of The Medium Type of Roosters in The Postal Cages
}

\author{
Angga Prasetyo Kurniawan, Khaira Nova, Dian Septinova, Riyanti \\ Departement of Animal Husbandry, Faculty of Agriculture, University of Lampung \\ Jl. Prof.Dr. Soemantri Brojonegoro No.1 Gedong Meneng Bandar Lampung 35145 \\ e-mail : Anggaptk13@gmail.com
}

\begin{abstract}
This study aimed to investigate the effect of the percentage of day and night rations on live weight, carcass weight, and giblet weight of medium type roosters in postal cages. This study used a completely randomized design (CRD), consisting of three treatments with six replications, namely P1: giving rations of $30 \%$ day and $70 \%$ night, $\mathrm{P} 2$ : giving rations of $50 \%$ day and $50 \%$ night, $\mathrm{P} 3$ : giving rations $70 \%$ day and $30 \%$ night. The data were analyzed using analysis of variance at the $5 \%$ level. The results showed that the percentage of different day and night rations had no significant effect $(\mathrm{P}>0.05)$ on live weight (694.33 to $699.67 \mathrm{~g} / \mathrm{head})$, carcass weight (405.67 to $407.50 \mathrm{~g} /$ head), and giblet weight (35.67 to 36.83 $\mathrm{g} /$ head). However, the percentage of $30 \%$ day and $70 \%$ night rations tended to have the best effect on the lowest giblet weight, namely $35.67 \mathrm{~g} /$ head for the 7 week old medium type rooster.
\end{abstract}

Keywords: Day and night percentage, Giblet, Rooster, Carcass weight, Live weight

\begin{abstract}
ABSTRAK
Penelitian ini bertujuan untuk mengetahui pengaruh persentase pemberian ransum pada siang dan malam hari terhadap bobot hidup, bobot karkas, dan bobot giblet pada ayam jantan tipe medium di kandang postal. Penelitian ini menggunakan Rancangan Acak Lengkap (RAL), terdiri atas tiga perlakuan dengan ulangan sebanyak enam kali, yaitu P1: pemberian ransum 30\% siang dan 70\% malam, P2: pemberian ransum 50\% siang dan 50\% malam, P3: pemberian ransum 70\% siang dan $30 \%$ malam. Data yang dihasilkan dianalisis dengan sidik ragam pada taraf 5\%. Hasil penelitian menunjukkan bahwa persentase pemberian ransum pada siang dan malam hari yang berbeda tidak berpengaruh nyata $(\mathrm{P}>0,05)$ terhadap bobot hidup ( 694,33 sampai 699,67 g/ekor), bobot karkas ( 405,67 sampai 407,50 g/ekor), dan bobot giblet ( 35,67 sampai 36,83 g/ekor). Namun demikian, persentase pemberian ransum 30\% siang dan $70 \%$ malam cenderung memberikan pengaruh terbaik terhadap bobot giblet yang paling rendah yakni 35,67 g/ekor pada ayam jantan tipe medium umur 7 minggu.
\end{abstract}

Kata Kunci: Ayam jantan, Bobot hidup ayam, Bobot karkas, Giblet, Persentase siang dan malam hari 


\section{PENDAHULUAN}

Seiring dengan perkembangan waktu, pertambahan jumlah penduduk, peningkatan pendapatan, dan kesadaran masyarakat akan arti pentingnya gizi bagi kesehatan tubuh, maka permintaan masyarakat akan kebutuhan pangan sumber protein hewani semakin meningkat

Salah satu pangan sumber protein hewani yang digemari oleh masyarakat adalah daging ayam. Daging ayam yang dikonsumsi biasanya berasal dari daging broiler dan daging ayam kampung. Namun, ketersedian akan ayam kampung masih terbatas dan harganya relatif mahal. Oleh sebab itu, ada alternatif lain yang digunakan untuk menggantikan daging ayam kampung yaitu daging ayam jantan tipe medium.

Ayam jantan tipe medium mempunyai kemiripan dengan ayam kampung yaitu untuk mendapatkan bobot tubuh $\pm 1,2 \mathrm{~kg}$ memerlukan waktu 3 --4 bulan. Selain itu, ayam jantan tipe medium mempunyai kandungan lemak daging rendah yang hampir setara dengan ayam kampung (Darma, 1982). Riyanti (1995) menyatakan ayam jantan tipe medium mempunyai bentuk tubuh dan kadar lemak yang menyerupai ayam kampung sehingga dapat digunakan untuk memenuhi kebutuhan konsumen yang mempunyai kebiasaan lebih menyukai ayam yang kadar lemaknya seperti ayam kampung.

Pemeliharaan ayam jantan tipe medium di kandang postal biasanya beralaskan litter. Kandang postal merupakan kandang tanpa halaman (umbaran), suatu tipe kandang pemeliharaan unggas dengan lantai kandangnya ditutup oleh bahan penutup lantai seperti sekam padi, serutan gergaji, tongkol jagung, dan jerami padi yang dipotong-potong (Sainsburry, 1995).

Masalah yang dihadapi ayam jantan tipe medium yang dipelihara secara intensif di kandang terbuka (open house) adalah suhu yang tinggi di siang hari ayam seringkali menderita akibat suhu tinggi, kelembaban tinggi dan ventilasi yang jelek. Suhu dan kelembaban udara yang tinggi pada siang akan menyebabkan konsumsi air minum meningkat, nafsu makan menurun sehingga konsumsi ransum rendah dan konversi ransum kurang baik. Sehingga hal tersebut juga berpengaruh terhadap bobot hidup, bobot karkas, dan giblet ayam jantan tipe medium. Sebaliknya, suhu dan kelembaban udara yang rendah pada malam akan menyebabkan konsumsi air minum menurun, nafsu makan meningkat sehingga konsumsi ransum tinggi dan konversi ransum menjadi lebih baik. Oleh sebab itu, diperlukan manajemen pemberian ransum, salah satunya dengan metode perbedaan persentase pemberian ransum antara siang dan malam hari untuk mencegah pemborosan ransum.

Metode persentase pemberian ransum siang dan malam bagi ayam jantan tipe medium, akan memberikan informasi pemberian ransum sesuai dengan suhu lingkungan. Pada sore hari dan sepanjang malam sampai menjelang pagi hari suhu rendah, ayam akan merasa nyaman dan akan makan lebih banyak dibandingkan dengan suhu udara lebih tinggi menjelang tengah hari hingga sore hari. Hal ini akan mempengaruhi pertumbuhan ayam yang juga akan mempengaruhi bobot hidup dan bobot karkas ayam.

Pencapaian bobot karkas sangat berkaitan erat dengan bobot potong dan pertambahan berat tubuh. Semakin besar bobot potong dan pertambahan berat tubuh maka bobot karkas akan semakin meningkat dan pertambahan berat lemak abdominal pun akan meningkat. (Parakkasi, 1998) Selanjutnya, Rasyaf (2011) menjelaskan bahwah bobot giblet meningkat dengan meningkatnya bobot karkas, walaupun persentase terhadap bobot hidup ayam akan menurun.

Berdasarkan uraian diatas, maka dilakukanlah penelitian tentang pengaruh persentase pemberian ransum pada siang dan malam hari terhadap bobot hidup, bobot karkas, dan bobot giblet pada ayam jantan tipe medium di kandang postal.

\section{MATERI DAN METODE}

\section{Waktu dan tempat}

Penelitian ini dilaksanakan pada 30 Agustus-18 Oktober 2018 selama 7 minggu, di kandang postal, Laboratorium Terpadu, Fakultas Pertanian, Universitas Lampung.

\section{Materi}

Alat yang digunakan dalam penelitian ini meliputi peralatan pemeliharaan ayam, peralatan pengmbilan data (timbangan elektrik, kompor, pisau, nampan, karung/plastik, dan panci).

Bahan yang digunakan dalam penelitian ini adalah ayam jantan tipe medium dengan ransum (BR1) PT Japfa Comfeed 


\section{Metode}

\section{Rancangan Percobaan}

Penelitian ini dilakukan secara eksperimental menggunakan Rancangan Acak Lengkap (RAL) 3 perlakuan dan 6 ulangan. Perlakuan yang diberikan adalah

P1: pemberian ransum $30 \%$ siang dan $70 \%$ malam.

P2: pemberian ransum $50 \%$ siang dan $50 \%$ malam.

P3: pemberian ransum $70 \%$ siang dan $30 \%$ malam.

\section{Peubah Yang Diamati}

\section{a. Bobot Hidup}

Bobot hidup (g/ekor) dilakukan dengan penimbangan ayam percobaan setelah dipuasakan selama 6 jam (Soeparno, 2005).

\section{b. Bobot Karkas}

Bobot karkas (g) ditimbang berdasarkan ayam tanpa darah, bulu, kepala sampai batas pangkal leher, kaki sampai batas lutut, dan organ dalam.

\section{Bobot Giblet}

Bobot giblet $(\mathrm{g})$ ditimbang berdasrkan bobot hati, jantung, dan gizzard yang telah dibersihkan dari kotoran (Kurtini, et al, 2011)

\section{Analisis Data}

Data dianalisis dengan analisis of variance (ANOVA) pada taraf 5\%, dan dilanjutkan dengan uji Duncan untuk mencari perlakuan terbaik.

\section{HASIL DAN PEMBAHASAN}

\section{Pengaruh Perlakuan terhadap Bobot Hidup Ayam Jantan Tipe Medium}

Hasil penelitian menunjukkan bahwa rata- rata bobot hidup (g/ekor) ayam jantan tipe medium umur 7 minggu pada masing-masing perlakuan dapat dilihat pada Tabel 1 Bobot hidup ayam jantan tipe medium pada umur 7 minggu.

Hasil dari penelitian (Tabel 1) didapatkan rata - rata bobot hidup ayam jantan tipe medium dengan persentase pemberian ransum 30\% siang dan $70 \%$ malam sebesesar $695,17 \mathrm{~g} / \mathrm{ekor}$, perlakuan persentase pemberian ransum 50\% siang dan 50\% malam sebesar 699,67 g/ekor, dan perlakuan persentase pemberian ransum $70 \%$ siang dan $30 \%$ malam sebesar 694,33 g/ekor. Berdasarkan analisis ragam bahwa perlakuan persentase pemberian ransum siang dan malam hari tidak berpengaruh nyata $(\mathrm{P}>0,05)$ terhadap bobot hidup ayam jantan tipe medium pada umur 7 minggu. Rata-rata dari bobot hidup ayam jantan tipe medium yang tidak berbeda nyata diduga karena perlakuan persentase pemberian ransum siang dan malam berbeda nyata terhadap konsumsi ransum tapi tidak berbeda nyata terhadap pertumbuhan bobot tubuh. Hal ini diduga ayam yang diberikan ransum sedikit di siang hari masih ingin makan namun ransum sudah habis, sehingga ayam lebih banyak bergerak dan minum, dimana hal ini mengakibatkan ransum yang dikonsumsi ayam tidak dikonversikan menjadi daging.

Hariyadi (2007) menyatakan bahwa bobot hidup yang dihasilkan sama karena pertumbuhan bobot badan tidak berbeda nyata pula. Keadaan ini terjadi dimungkinkan karena nutrien ransum yang dikonsumsi tersebut dalam tubuh digunakan hanya untuk kebutuhan hidup pokok saja belum mencukupi untuk pertumbuhan organ tubuh lainya.

Persentase pemberian ransum siang dan malam yang berpengaruh tidak nyata terhadap bobot hidup diduga pula disebabkan oleh suhu udara dalam kandang. Suhu nyaman ayam jantan tipe medium berkisar $26--27^{\circ} \mathrm{C}$ (Czarick dan Fairchild, 2008). Kelembaban kandang yang sesuai untuk ayam yaitu berkisar antara 50--70\%. (Borges, et al., 2004). Kelrmbaban pada penelitian ini tidak sesuai dengan suhu nyaman ayam yakni 27,36$69,94^{\circ} \mathrm{C}$ dan ditambah lagi kandang penelitian ini menggunakan kandang postal beralasan liiter yang tidak sebaik kandang panggung yang sirkulasi udaranya lebih baik dibandingkan kandang postal. 
Tabel 1. Bobot hidup ayam jantan tipe medium pada umur 7 minggu

\begin{tabular}{|c|c|c|c|}
\hline \multirow{2}{*}{ Ulangan } & \multicolumn{3}{|c|}{ Perlakuan } \\
\hline & $\mathrm{P} 1$ & $\mathrm{P} 2$ & P3 \\
\hline & \multicolumn{3}{|c|}{ 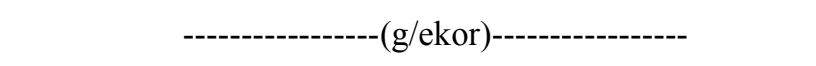 } \\
\hline 1 & 727 & 677 & 692 \\
\hline 2 & 690 & 701 & 721 \\
\hline 3 & 687 & 723 & 703 \\
\hline 4 & 692 & 685 & 708 \\
\hline 5 & 678 & 704 & 655 \\
\hline 6 & 697 & 708 & 687 \\
\hline Jumlah & 4.171 & 4.198 & 4.166 \\
\hline Rata-rata & 695,17 & 699,67 & 694,33 \\
\hline
\end{tabular}

Keterangan :

R1 : pemberian ransum $30 \%$ siang dan $70 \%$ malam

R2 : pemberian ransum $50 \%$ siang dan $50 \%$ malam

R3 : pemberian ransum $70 \%$ siang dan $30 \%$ malam
Rata-rata bobot hidup ayam jantan tipe medium dikandang postal pada penelitian ini berkisar antara 694,33 dan 699,67 \%, lebih rendah dibandingkan dengan rata-rata bobot hidup ayam jantan tipe medium dikandang panggung penelitian Cintia, A (2012), yaitu berkisar antara 739, 167 dan 755, $833 \%$. Perbedaan ini disebabkan oleh suhu pada kandang postal yang beralaskan litter lebih panas dibandingan dengan kandang panggung yang sirkulasi udaranya lebih baik.

\section{Pengaruh Perlakuan terhadap Bobot Karkas Ayam Jantan Tipe Medium}

Hasil penelitian menunjukkan bahwa rata - rata bobot karkas (g/ekor) ayam jantan tipe medium umur 7 minggu pada masing masing perlakuan dapat dilihat pada Tabel 2 Bobot karkas ayam jantan tipe medium pada umur 7 minggu. Hasil dari penelitian ini (Tabel 2) didapatkan rata-rata bobot karkas pada perlakuan persentase pemberian ransum 30\% siang dan 70\% malam adalah 405,67 g/ekor, perlakuan persentase pemberian ransum $50 \%$ siang dan 50\% malam sebesar $407 \mathrm{~g}$ /ekor, dan perlakuan $70 \%$ siang dan $30 \%$ malam sebesar 407,50 g/ekor.

Berdasarkan analisis ragam perlakuan persentase pemberian ransum siang dan malam hari tidak berpengaruh nyata $(\mathrm{P}>0,05)$ terhadap bobot karkas ayam jantan tipe medium pada umur 7 minggu. Hal ini menunjukkan bahwa metode pemberian ransum siang dan malam hari yang tidak berbeda nyata memengaruhi total bobot karkas ayam jantan tipe medium umur 7 minggu di kandang postal.

Bobot karkas yang tidak berbeda nyata diduga dipengaruhi oleh bobot hidup yang tidak berbeda nyata pula. Bobot karkas seekor ayam erat hubungannya dengan bobot hidup ayam waktu panen. Soeparno (2005) menyakan salah satu faktor yang memengaruhi bobot karkas adalah bobot hidup. Selanjutnya ditambahkan oleh Purba (1990), bobot hidup rendah menghasilkan bobot karkas rendah karena komponen utama karkas adalah tulang dan otot.

Bobot karkas tidak nyata juga diduga karena perbedaan ransum yang dikonsumsi belum mampu memberikan pengaruh yang nyata terhadap pertumbuhan tulang dan otot ayam sebagai komponen utama bagi tubuh ayam. Hal ini sesuai dengan pendapat Rasyaf 
(2011) yang menyatakan bahwa produksi karkas erat hubunganya dengan bobot hidup, semakin bertambah bobot hidup produksi karkas akan semakin bertambah. Hal ini menyebabkan bobot hidup tidak nyata, sehingga bobot karkaspun tidak nyata.

Rata-rata bobot karkas ayam jantan tipe medium dikandang postal pada penelitian ini berkisar antara 405,67 dan 407,70 (g/ekor), lebih rendah dibandingkan dengan rata-rata bobot hidup ayam jantan tipe medium dikandang panggung penelitian Cintia, A
(2012), yaitu berkisar antara 440,37 dan 458,78 (g/ekor). Perbedaan ini disebabkan oleh aktifitas gerak ayam lebih banyak bergerak pada siang hari untuk menyetabilkan suhu tubuh karena pada siang hari suhu pada kandang postal yang panas, hal ini disebabkan sirkulasi kandang postal yang tidak sebaik kandang panggung, sehingga ayam lebih banyak minum dibandingkan mengkonsumsi ransum.

Tabel 2. Bobot karkas ayam jantan tipe medium pada umur 7 minggu

\begin{tabular}{cccc}
\hline & & Perlakuan & \\
\cline { 2 - 3 } Ulangan & P1 & P2 & P3 \\
\cline { 2 - 3 } 1 & & - (g/ekor)------------ & \\
2 & 431 & 402 & 411 \\
3 & 400 & 372 & 442 \\
4 & 404 & 426 & 418 \\
5 & 402 & 398 & 434 \\
6 & 414 & 419 & 314 \\
\hline Jumlah & 383 & 425 & 426 \\
\hline Rata-rata & 2.434 & 2.442 & 2.445 \\
\hline
\end{tabular}

Keterangan:

R1 : pemberian ransum $30 \%$ siang dan $70 \%$ malam

R2 : pemberian ransum $50 \%$ siang dan $50 \%$ malam

R3 : pemberian ransum $70 \%$ siang dan $30 \%$ malam

\section{Pengaruh Perlakuan terhadap Bobot Giblet Ayam Jantan Tipe Medium}

Hasil penelitian menunjukkan bahwa rata-rata bobot giblet ayam jantan tipe medium selama penelitian berkisar antara 35,67 g/ekor dan 36,83 g/ekor, dapat dilihat pada Tabel 3 Bobot giblet ayam jantan tipe medium pada umur 7 minggu. Hasil dari penelitian ini (Tabel 3) didapatkan rata-rata bobot giblet pada perlakuan pemberian ransum $30 \%$ siang dan $70 \%$ malam sebesar 35,67 g/ekor, pemberian ransum $40 \%$ siang dan $50 \%$ malam sebesar
$35,59 \mathrm{~g} /$ ekor, dan pemberian rasum $70 \%$ siang dan 30\% malam sebesar 36,83 g/ekor.

Berdasarkan analisis ragam perlakuan persentase pemberian ransum siang dan malam hari tidak berpengaruh nyata $(\mathrm{P}>0,05)$ terhadap bobot giblet ayam jantan tipe medium pada umur 7 minggu. Hal ini menunjukkan bahwa metode pemberian ransum siang dan malam hari yang berbeda tidak memengaruhi total bobot giblet ayam jantan tipe medium umur 7 minggu di kandang postal.

Bobot giblet yang tidak nyata pada penelitian ini diduga karena ayam jantan tipe medium memiliki bobot hidup yang relatif 
sama, sehingga bobot giblet relatif sama antar perlakuan. Bobot giblet sangat dipengaruhi oleh bobot hidup ayam.

Soeparno (2005) menyatakan bobot hidup mempengaruhi bobot giblet, semakin besar bobot hidup maka bobot giblet yang dihasilkan akan meningkat. Ransum yang diberikan pada masing-masing perlakuan adalah ransum komersial berbentuk crumble dengan kandungan nutrisi serat kasar 5,37 \%.

Bobot giblet yang tidak nyata ini, diduga juga disebabkan oleh konsumsi serat kasar ayam jantan tipe medium pada masing-masing perlakuan. Berdasarkan analisis ragam konsumsi serat kasar yang berkisar dari
13,33 g/ekor dan 13,96 g/ekor untuk dicerna dalam tubuh ayam tidak berpengaruh nyata $(\mathrm{P}>0,05)$ terhadap konsumsi serat kasar ayam jantan tipe medium. Hal inilah yang menyebabkan perlakuan perbedaan persentase pemberian ransum siang dan malam tidak berpengaruh nyata terhadap bobot giblet.

Wahju (1992) menyatakan kandungan serat kasar yang diperbolehkan untuk unggas yaitu tidak lebih dari 6\%. Kandungan serat kasar yang sama membuat kerja gizzard dalam mencerna makanan akan sama sehingga bobot giblet yang dihasilkan akan relatif sama.

Tabel 3. Bobot giblet ayam jantan tipe medium pada umur 7 minggu

\begin{tabular}{cccc}
\hline & & Perlakuan & \\
\cline { 2 - 3 } Ulangan & $\mathrm{R} 1$ & $\mathrm{R} 2$ & $\mathrm{R} 3$ \\
\cline { 2 - 4 } 1 & & 39 & \\
2 & 36 & 34 & 34 \\
3 & 34 & 34 & 39 \\
4 & 40 & 36 & 36 \\
5 & 33 & 36 & 39 \\
6 & 39 & 36 & 34 \\
\hline Jumlah & 32 & 215 & 221 \\
\hline Rata-rata & 214 & 35,83 & 36,83 \\
\hline
\end{tabular}

Keterangan:

R1 : pemberian ransum $30 \%$ siang dan $70 \%$ malam

R2 : pemberian ransum $50 \%$ siang dan $50 \%$ malam

R3 : pemberian ransum $70 \%$ siang dan $30 \%$ malam

Kandungan serat kasar ransum pada penelitian ini masih dalam toleransi yang diperbolehkan $(5,37 \%)$ untuk unggas, hal ini mengakibatkan gizzard ayam jantan tipe medium pada masing - masing perlakuan tidak bekerja lebih berat untuk mencerna serat kasar sehingga bobot giblet menjadi tidak nyata. Dharmawati dan Ari (2012) menyatakan meningkatnya bobot giblet bukan disebabkan oleh meningkatnya pertumbuhan. Melainkan karena fungsinya yang cukup berat dalam mencerna bahan makanan menjadi partikel yang lebih kecil, juga untuk mengaduk bahan tersebut dengan enzim dengan enzim pencernaan yang dihasilkan proventikulus maupun empedu, sehingga pembesaran giblet ini sangat dipengaruhi oleh banyak dan sifat serat kasar bahan pakan. 


\section{SIMPULAN DAN SARAN}

\section{Simpulan}

Berdasarkan hasil penelitian dapat disimpulkan bahwa

(1). Metode persentase pemberian ransum pada siang dan malam hari menghasilkan pengaruh tidak nyata $(\mathrm{P}>0,5)$ terhadap bobot hidup, bobot karkas, dan bobot giblet ayam jantan tipe medium umur 7 minggu.

(2) Metode persentase pemberian ransum 30\% siang dan $70 \%$ malam memberikan pengaruh terbaik terhadap bobot giblet yang paling rendah yakni 35,67 g/ekor pada ayam jantan tipe medium umur 7 minggu.

\section{Saran}

Perlu dilakukan penelitian lebih lanjut tentang pengaruh metode pemberian ransum siang dan malam hari dengan memberikan pakan pada jam-jam tertentu seperti jam 12 malam dan 6 pagi.

\section{DAFTAR PUSTAKA}

Cintia, A. 2012 "Pengaruh Metode Pemberian Ransum Pada siang dan Malam hari Terhadap Bobot Hidup, Bobot Karkas, dan Giblet Ayam Jantan Tipe Medium Dikandang Postasl". Skripsi. Fakulas Pertanian. Universitas Lampung. Lampung

Czarick III. M. dan B.D. Fairchild. 2008. Poultry housing for hot climates. In: Daghir NJ, editor. Poult Prod hot Clim. Trowbridge (UK): Cromwell Press. P. 1131

Darma, M. 1982. “Tanggapan Ayam Jantan Pedaging terhadap Mutu Ransum pada Awal Pertumbuhan". Karya Ilmiah. Fakultas Peternakan, Institut Pertanian Bogor. Bogor
Dharmawati, S dan J. K. Ari 2012. Pengaruh penggunaan tepung daun alang-alang (imprata cylindricaii) dalam ransum terhadap kadar lemak, kolesterol karkas dan organ pencernaan itik alabio jantan. Ziaraa'h Vol.34 No.2:150-160

Dinas Peternakan. 2009. Statistik Peternakan. Dinas Peternakan. Dinas Peternakan Provinsi Lampung. Bandar Lampung

Hariyadi, D. 2007. Pengaruh Pemanfaatan Bakteri Penghasil Fitase (Pantoea Angglomerans) dalam Ransum Terhadap Kualitas Karkas Ayam Broiler. [Skripsi]. Fakultas Pertanian Universitas Sebelas Maret Surakarta. Surakarta

Kurtini, T., K. Nova dan D. Septinova. 2011. "Pengaruh Berbagai Tingkat Pemberian Jumlah Ransum Komersial terhadap Penampilan Anak Ayam Kampung”. Laporan Penelitian. Fakultas Pertanian Universitas Lampung. Bandar Lampung

Parakkasi, A. 1998. Ilmu Gizi dan Makanan Ternak Monogastrik. Cetak ke 1. Angkasa. Bandung

Purba, D.K. 1990. "Perbandingan Karkas dan Nonkarkas pada Ayam Jantan Kampung, Petelur, dan Broiler Umur 6 Minggu". Karya ilmiah. Fakultas Peternakan. Institut Pertanian Bogor. Bogor

Rasyaf, M. 2011. Panduan Berternakn Ayam Pedaging. Cetakan ke- 4 Penebar. Swadaya. Jakarta

Riyanti. 1995. Pengaruh Berbagai Imbangan Energi Protein Ransum terhadap Performans Ayam Jantan Petelur Tipe Medium. Prosiding Seminar Nasional Sains dan Teknologi Peternakan. Balai Penelitian Ternak. Ciawi. Bogor

Sainsburry, D. 1995. Poultry Health and Management. Chikens Turkeys, Ducks, Geese, Quile. 3rd ed. University of Cambridge. United Kingdom 
Soeparno. 2005. Ilmu dan Teknologi Daging. Edisi ke-4. Gajah Mada University Press. Yogyakarta

Wahju, J. 1992. Ilmu Nutrisi Unggas. Cetakan ke-3. Gadjah Mada University Press. Yogyakarta 